\title{
Improved embryo survival following follicular drainage of subordinate follicles for twin pregnancy prevention in bi-ovular dairy cows
}

\author{
Irina GARCIA-ISPIERTO' ${ }^{1,2)}$ and Fernando LÓPEZ-GATIUS', 3) \\ 1) Department of Animal Science, University of Lleida, 25198 Lleida, Spain \\ 2) Agrotecnio Centre, University of Lleida, 25198 Lleida, Spain \\ 3) Transfer in Bovine Reproduction SLu, 22300 Barbastro, Spain
}

\begin{abstract}
To prevent twin pregnancies in cattle, a simple transvaginal device can be used for follicular drainage. This study examines embryo survival following follicular drainage of the smaller pre-ovulatory follicle at timed artificial insemination (AI) in cows with a pre-ovulatory follicle in each ovary. The study groups established were a control group of 289 monovular cows, a non-drainage group of 114 bi-ovular cows and a follicular drainage group of 113 bi-ovular cows. All cows undergoing drainage developed a corpus luteum (CL) in the drained ovary. Pregnancy loss was recorded 56 days post-AI in $19.5 \%$ of the 149 cows that became pregnant. Pregnancy loss in the drainage group cows not suffering heat stress (3.8\%) was significantly lower $(\mathrm{P}<0.05)$ than in control non-heat stressed cows $(20.9 \%)$ and heat-stressed non-drainage group cows $(25 \%)$. Results indicate that CL induction by follicular drainage for twin pregnancy prevention may reduce the incidence of pregnancy loss.
\end{abstract} Key words: Double ovulation, Follicular co-dominance, Ovulation failure, Simplified transvaginal device

(J. Reprod. Dev. 66: 93-96, 2020)

$\mathbf{T}$ winning rates in dairy herds have increased considerably over the last 30 years [1], probably due to a higher double ovulation rate related to high milk production [2]. Double ovulation can occur in as many as $25 \%$ of high producing dairy cows during their third or later lactations [3]. In the years to come, it is therefore likely that the twinning rate will continue to increase in parallel with milk production. While twin births are welcome for the economy of beef cattle breeding [4-6], twin pregnancy is not desirable in dairy cattle. With an economic burden of up to $\$ 225$ per twin pregnancy [7], the risk of pregnancy loss during the first trimester of gestation for cows carrying twins may be three to seven times higher than for cows carrying singletons [1]. Besides pregnancy loss, the reproductive performance and productive lifespan of a cow delivering twins are greatly reduced. In effect, a mean production lifespan shorter by 200 days has been reported for cows delivering twins rather than singletons [8]. These are cogent reasons to try to reduce the incidence of twin births.

Proposed approaches to mitigate the negative effects of twin pregnancies involve hormone therapy or artificial embryo reduction. As an example, gonadotropin-releasing hormone (GnRH) treatment during pregnancy diagnosis (days 28-34 post-artificial insemination [AI]) increases pregnancy survival in cows carrying twins and is accompanied by an increase in the spontaneous twin reduction rate [9]. Under field conditions, manual rupture of the amniotic vesicle

Received: May 15, 2019

Accepted: October 30, 2019

Advanced Epub: November 16, 2019

(C)2020 by the Society for Reproduction and Development

Correspondence: F López-Gatius (e-mail: lopezgatiusf@gmail.com)

This is an open-access article distributed under the terms of the Creative Commons Attribution Non-Commercial No Derivatives (by-nc-nd) License. (CC-BY-NC-ND 4.0: https://creativecommons.org/licenses/by-nc-nd/4.0/) or transvaginal ultrasound-guided aspiration of allanto-amniotic fluid may reduce twinning $[1,7]$. However, hormone therapy does not prevent twinning and inducing twin reduction may increase the risk of pregnancy loss. Placental fusion leading to anastomosis of allantochorionic blood vessels between the two embryos during the late embryonic period, widely described in twin pregnant cows $[10,11]$, is perhaps the main cause of pregnancy failure after induced reduction of twins. Ultrasound-guided puncture and drainage without suction of subordinate follicles during insemination has recently proved to be an efficient procedure to eliminate the risk of twin pregnancy without reducing fertility $[12,13]$. This technique overcomes the risk of pregnancy loss related to the process of induced twin reduction and increases the incidence of additional corpora lutea. In one study, all cows developed a corpus luteum (CL) in the drained ovary and these luteal structures were functional [13]. Further, the function of drainage-induced CL was improved with GnRH treatment on day 7 post-drainage [13]. As a number of corpora lutea exceeding the number of embryos is a strong factor promoting pregnancy maintenance [14], we hypothesized that CL induction by follicular drainage may reduce the subsequent risk of pregnancy loss. Thus, the aim of the present study was to examine embryo survival following follicular drainage of the smaller pre-ovulatory follicle at timed AI in cows with a pre-ovulatory follicle in each ovary. For follicle puncture and drainage, we used a simple in-house trans-vaginal device.

On day 7 post-AI, 13 cows were withdrawn from the study: eight control group cows with two corpora lutea, two non-drainage group cows, and three drainage group cows with three corpora lutea. This resulted in a final study population of 516 cows: 289 monovular cows in the control group, 114 bi-ovular cows in the non-drainage group, and 113 bi-ovular cows in the drainage group. Two hundred and thirty-four cows $(45.3 \%)$ were inseminated under heat stress conditions (maximum temperature-humidity index $[\mathrm{THI}]>72$ ). 
Table 1. Effects of heat stress (maximum temperature-humidity index $[\mathrm{THI}]>72$ ) and follicular drainage at artificial insemination $(\mathrm{AI})$ on ovulation failure, pregnancy, twin pregnancy, and pregnancy loss ( $=516: 289$ with one pre-ovulatory follicle and 227 cows with a pre-ovulatory follicle in each ovary)

\begin{tabular}{ccccccc}
\hline Number of follicles & Drainage * & THI $>72$ & Ovulation failure ** & Pregnancy & Twins *** & Pregnancy loss *** \\
\hline One & No & No $(\mathrm{n}=144)$ & $3(2.1 \%)$ & $43(29.9 \%)$ & 0 & $9(20.9 \%)^{\mathrm{a}}$ \\
& & Yes $(\mathrm{n}=145)$ & $7(4.8 \%)$ & $30(20.7 \%)$ & 0 & $10(33.3 \%)^{\mathrm{a}}$ \\
\hline \multirow{2}{*}{ Two } & No & No $(\mathrm{n}=69)$ & $2(2.9 \%)$ & $26(37.7 \%)$ & $8(30.8 \%)^{\mathrm{a}}$ & $4(15.4 \%)^{\mathrm{ab}}$ \\
& & Yes $(\mathrm{n}=45)$ & $5(11.1 \%)$ & $12(26.7 \%)$ & $2(16.7 \%)^{\mathrm{b}}$ & $3(25 \%)^{\mathrm{a}}$ \\
& \multirow{2}{*}{ Yes } & No $(\mathrm{n}=69)$ & $12(17.4 \%)$ & $26(37.7 \%)$ & 0 & $1(3.8 \%)^{\mathrm{b}}$ \\
& & Yes $(\mathrm{n}=44)$ & $13(29.5 \%)$ & $12(27.3 \%)$ & 0 & $2(16.7 \%)^{\mathrm{ab}}$ \\
\hline
\end{tabular}

* Drainage of the smaller follicle in cows with a pre-ovulatory follicle in each ovary. ** In cows with two follicles at AI: for all follicles in the non-drainage group and for the dominant follicle in the drainage group. ${ }^{* * *}$ In pregnant cows. Values with different superscripts differ significantly within columns when tested using the Tukey-Kramer test $(\mathrm{P}<0.05)$.

Table 1 shows the effects of heat stress and follicular drainage at AI on ovulation failure, pregnancy, twin pregnancy, and pregnancy loss. After drainage, all cows developed a CL in the drained ovary and ovulation failure of the dominant follicle occurred in 25 of the 113 cows subjected to drainage $(22.1 \%)$. No pregnancies were produced in these 25 cows. Pregnancy loss was recorded 56 days post-AI in $19.5 \%$ of the 149 cows that became pregnant. Pregnancy loss in cows in the drainage group not subjected to heat stress conditions $(3.8 \%)$ was significantly lower $(\mathrm{P}<0.05)$ than in control cows kept in similar conditions $(20.9 \%)$ and heat-stressed cows in the control $(33.3 \%)$ and non-drainage $(25 \%)$ groups. In the non-drainage group, double ovulation was observed in 61 cows $(53.5 \%)$ and twin pregnancy in 10 of the 38 pregnant cows $(26.3 \%)$. The twin pregnancy rate in the non-drainage group heat-stressed cows $(16.7 \%)$ was significantly lower $(\mathrm{P}<0.05)$ than in non-heat stressed cows $(30.8 \%)$. No twins were recorded in the drainage group.

Mean milk production, days in milk at AI, and number of lactations were $43.5 \pm 9.5 \mathrm{~kg}, 125.0 \pm 72.1$ days, and $2.8 \pm 1.8$ lactations, respectively (mean $\pm \mathrm{SD}$ ). No significant differences in these values among the control, non-drainage, and drainage groups were detected by the Student's $t$-test.

In the present study, follicular drainage of the subordinate follicle at AI, improved embryo survival in bi-ovular cows not subjected to heat stress compared to non-stressed control (monovular) cows and to heat-stressed cows in the control and non-drainage (bi-ovular) groups. Hence, our starting hypothesis, that $\mathrm{CL}$ induction by follicular drainage would reduce the pregnancy loss rate, was supported. Although our study population was small, CL induction by follicular drainage for twin pregnancy prevention was able to significantly ( $\mathrm{P}$ $<0.05$ ) reduce the incidence of pregnancy loss.

Drainage without suction seems to leave a sufficient number of granulosa cells in the follicle, which subsequently become luteal tissue. By reinforcing the function of these additional luteal structures using GnRH treatment 7 days after drainage [13], the subsequent risk of pregnancy loss may be reduced. In essence, induced additional corpora lutea seem to promote pregnancy maintenance in a similar way to additional corpora lutea following spontaneous ovulation [14].

Fertility was similar in the different groups. However, although follicular puncture did not affect the pregnancy rate, in the drainage group $22.3 \%$ of dominant follicles failed to ovulate as observed in previous studies $[12,13]$. This suggests that the drainage procedure could impair fertility or that fertility may be improved in cows subjected to drainage in which the dominant follicle ovulated. In effect, $43.2 \%$ of the 88 drainage group cows in which the non-drained dominant follicle ovulated became pregnant. This figure is more than acceptable when compared to $27.3 \%(111 / 403)$ of all pregnancies in remaining groups. However, this is a point to be improved. Treatment with a further dose of GnRH or human chorionic gonadotropin (hCG) at the time of insemination could improve the chances of ovulation for the dominant follicle. Further comprehensive studies are necessary to confirm these assertions.

Here, the use of a simple transvaginal device proved valuable for follicular puncture and drainage of the smaller pre-ovulatory follicle at timed AI in cows with a pre-ovulatory follicle in each ovary. The risk of twin pregnancy was eliminated and results were comparable to those obtained through ultrasound-guided puncture and drainage $[12,13]$. Pre-ovulatory follicles are usually easily palpable for an experienced clinician. Further studies should asses the efficiency of the procedure in cows with two pre-ovulatory follicles in the same ovary.

As an overall conclusion, our hypothesis that CL induction by follicular drainage to prevent twin pregnancy may reduce the subsequent risk of pregnancy loss was confirmed. In bi-ovular cows not subjected to heat-stress conditions, the pregnancy loss rate following follicular puncture and drainage was significantly lower than the rate recorded in monovular cows under similar environmental conditions.

\section{Methods}

\section{Experimental animals}

This study was performed over the period April 2018 to February 2019 in a commercial dairy herd of Holstein-Friesian lactating dairy cows reared in north-eastern Spain (41.13 latitude, -2.4 longitude). Only healthy cows with a $2.5-3.5$ body condition score on a scale of 1 to 5 [15], producing more than $30 \mathrm{~kg}$ milk per day, free of detectable reproductive disorders, and free of clinical diseases during the study period (days -5 to +60 from insemination) were included. Cows were selected from groups synchronized for fixed-time insemination [16] treated using a controlled intravaginal progesterone-releasing device (CIDR) (CIDR, containing $1.38 \mathrm{~g}$ of progesterone; Zoetis Spain SL, 

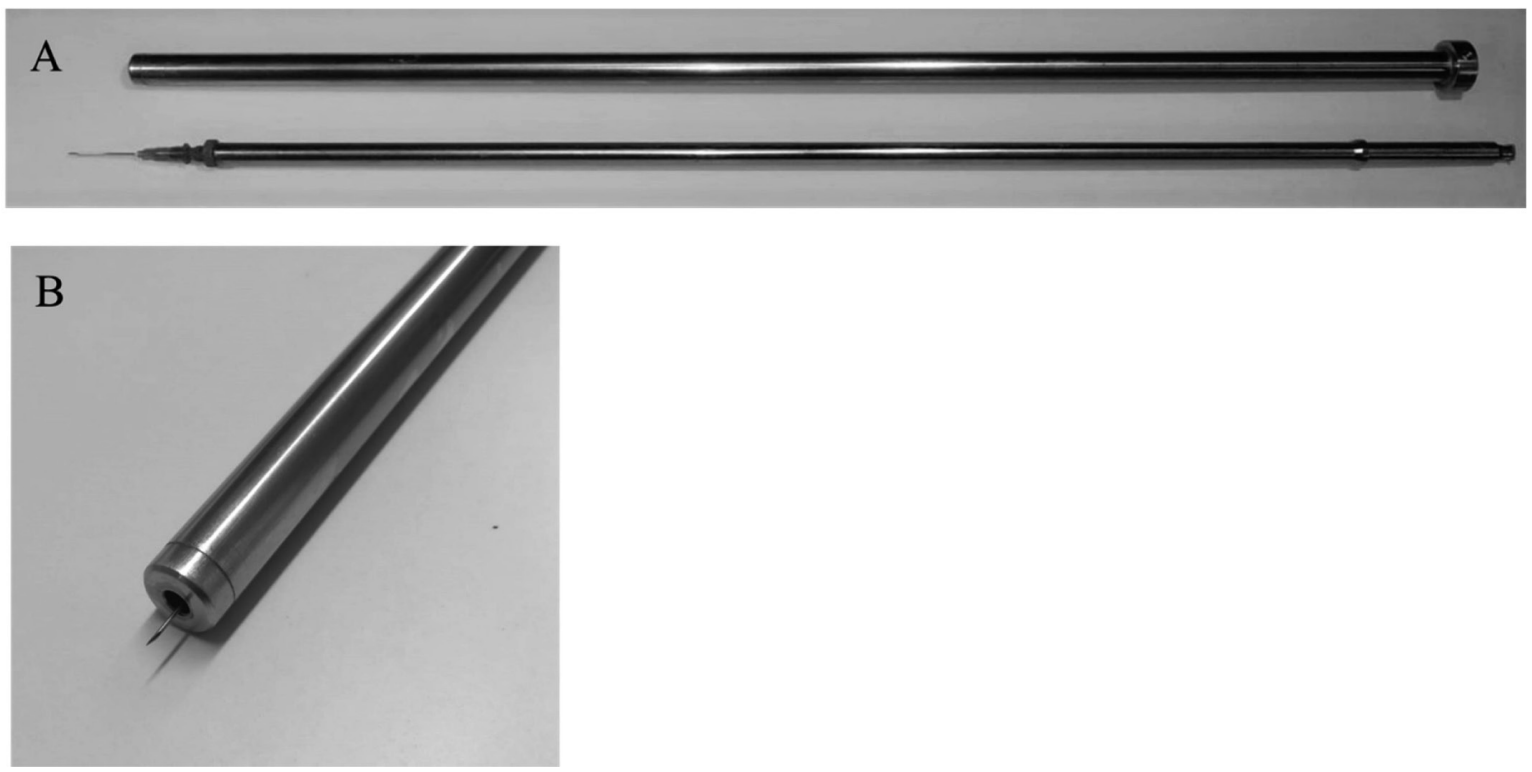

Fig. 1. Steel transvaginal cannula consisting of a sleeve and inner cannula fitted with an $18 \mathrm{G}$ needle for puncturing of the subordinate follicle (A). Flat end of the assembled cannula with needle emerging from center (B).

Alcobendas, Madrid, Spain) plus a GnRH agonist (dephereline: $100 \mu$ g gonadorelin acetate [6-D-Phe] i.m; Gonavet Veyx, Ecuphar, Barcelona, Spain) upon CIDR insertion. The CIDR was left in place for 5 days, and these animals were given cloprostenol (500 $\mu$ g i.m.; PGF Veyx Forte, Ecuphar, Barcelona, Spain) on CIDR removal. Twenty-four and $36 \mathrm{~h}$ later, the cows received a second cloprostenol dose and a second GnRH dose, respectively, and were inseminated 50-56 h after CIDR removal. Both ultrasonography (a portable B-mode ultrasound scanner equipped with a linear 5-10 $\mathrm{MHz}$ transvaginal transducer) and manual rectal palpation were used to confirm if a cow was in estrus and ready for insemination [14]. Only cows either with a pre-ovulatory follicle or with two bilateral co-dominant (ovulatory) follicles (one follicle per ovary) over $12 \mathrm{~mm}$ in diameter in the absence of a CL were included in the study. Further prerequisites were a uterus that was highly tonic and contractile to touch, and a vaginal discharge of copious clear fluid. As double ovulation has been related to the least possible size difference between the larger and smaller follicle, irrespective of the individual diameter of each follicle [17], only bi-ovular cows with a size difference less than $2 \mathrm{~mm}$ between the two co-dominant follicles were included in the study.

\section{Follicular drainage and experimental design}

Bi-ovular cows were randomly assigned to a non-drainage $(\mathrm{n}=$ $114)$ or follicular drainage $(n=113)$ group. On the same day of AI, monovular cows were assigned to a control group $(n=297)$. In the drainage group, the subordinate (smaller) follicle was punctured and drained with the help of a steel transvaginal cannula designed for follicular cyst puncture (Fig. 1a; Minitub Ibérica S.L., La Selva del Camp, Tarragona, Spain). Immediately before follicular puncture, the cannula, vulva, and the perineal region of the cow were washed with disinfectant solution. Ovaries bearing subordinate follicles were positioned adjacent to the vaginal wall by rectal manipulation. The end of the cannula (outer cannula sleeve: $1.2 \mathrm{~cm}$ outer diameter/50 $\mathrm{cm}$ length) was introduced into the dorsal vaginal fornix, to the left or right of the cervix depending on the side of the pre-ovulatory follicle to be punctured. The ovary with the pre-ovulatory follicle was then positioned transrectally against the flat end of the cannula sleeve (Fig. 1b) such that the follicle was separated only by the vaginal wall. The inner cannula $(0.8 \mathrm{~cm}$ outer diameter $/ 49.5 \mathrm{~cm}$ length $)$ fitted with a sterile $18 \mathrm{G} 25-\mathrm{mm}$ long needle was inserted in the ovary, and the vaginal wall subsequently pierced in a cranial direction through the fornix and the needle introduced into the follicular antrum as previously described [12]. No suction was performed. Cows underwent AI immediately after follicle puncture. To improve luteal function of the draining-induced CL [13], cows in the drainage group received a further GnRH dose on day 7 post-AI. This treatment improved $\mathrm{CL}$ function and increased plasma progesterone concentrations on day 21 post-AI [13].

Ovulation was recorded as the presence of a CL assessed seven days post-AI. Pregnancy diagnosis was performed by ultrasonography 28 days post-AI and embryo survival assessed 56 days post-AI. All procedures were approved by the Ethics Committee on Animal Experimentation of the University of Lleida (license number CEEA.06-01/12).

A clear negative effect of heat stress from May to September on the reproductive performance of lactating dairy cows has been described extensively in our geographical area $[18,19]$ whereby ovulation failure increases dramatically under heat stress conditions [3, 20]. The THI was recorded on the day of AI and THI values higher than 72 were considered heat stress conditions [21]. Differences between groups in proportions of different reproductive parameters were identified by Tukey-Kramer multiple comparison tests. 


\section{Acknowledgments}

The authors thank Ana Burton for her assistance with the English translation. This study received financial support from the procedure "01.02.01 de Transferència Tecnològica del Programa de desenvolupament rural de Catalunya 2014-2020" (Number 19005).

\section{References}

1. López-Gatius F, Andreu-Vázquez C, Mur-Novales R, Cabrera VE, Hunter RHF. The dilemma of twin pregnancies in dairy cattle. A review of practical prospects. Livest Sci 2017; 197: 12-16. [CrossRef]

2. Fricke PM, Wiltbank MC. Effect of milk production on the incidence of double ovulation in dairy cows. Theriogenology 1999; 52: 1133-1143. [Medline] [CrossRef]

3. López-Gatius F, López-Béjar M, Fenech M, Hunter RHF. Ovulation failure and double ovulation in dairy cattle: risk factors and effects. Theriogenology 2005; 63: 1298-1307. [Medline] [CrossRef]

4. Echternkamp SE, Roberts AJ, Lunstra DD, Wise T, Spicer LJ. Ovarian follicular development in cattle selected for twin ovulations and births. J Anim Sci 2004; 82: 459-471. [Medline] [CrossRef]

5. Dahlen CR, DiCostanzo A, Spell AR, Lamb GC. Use of embryo transfer seven days after artificial insemination or transferring identical demi-embryos to increase twinning in beef cattle. J Anim Sci 2012; 90: 4823-4832. [Medline] [CrossRef]

6. Hashiyada Y. The contribution of efficient production of monozygotic twins to beef cattle breeding. J Reprod Dev 2017; 63: 527-538. [Medline] [CrossRef]

7. Mur-Novales R, López-Gatius F, Fricke PM, Cabrera VE. An economic evaluation of management strategies to mitigate the negative effect of twinning in dairy herds. $J$ Dairy Sci 2018; 101: 8335-8349. [Medline] [CrossRef]

8. Andreu-Vázquez C, Garcia-Ispierto I, Ganau S, Fricke PM, López-Gatius F. Effects of twinning on the subsequent reproductive performance and productive lifespan of highproducing dairy cows. Theriogenology 2012; 78: 2061-2070. [Medline] [CrossRef]

9. Garcia-Ispierto I, López-Gatius F. The effects of a single or double GnRH dose on pregnancy survival in high producing dairy cows carrying singletons or twins. $J$ Reprod Dev 2018; 64: 523-527. [Medline] [CrossRef]

10. Williams G, Gordon I, Edwards J. Observations on the frequency of fused foetal circulations in twin-bearing cattle. Br Vet $J$ 1963; 119: 467-472. [CrossRef]

11. Echternkamp SE. Fetal development in cattle with multiple ovulations. J Anim Sci 1992 70: 2309-2321. [Medline] [CrossRef]

12. López-Gatius F, Hunter R. Puncture and drainage of the subordinate follicles at timed artificial insemination prevents the risk of twin pregnancy in dairy cows. Reprod Domest Anim 2018; 53: 213-216. [Medline] [CrossRef]

13. López-Gatius F, Garcia-Ispierto I, Serrano-Pérez B, Balogh OG, Gábor G, Hunter RHF. Luteal activity following follicular drainage of subordinate follicles for twin pregnancy prevention in bi-ovular dairy cows. Res Vet Sci 2019; 124: 439-443. [Medline] [CrossRef]

14. López-Gatius F. Factors of a noninfectious nature affecting fertility after artificial insemination in lactating dairy cows. A review. Theriogenology 2012; 77: 1029-1041. [Medline] [CrossRef]

15. Edmondson AJ, Lean IJ, Weaver CO, Farver T, Webster G. A body condition scoring chart for Holstein dairy cows. J Dairy Sci 1989; 72: 68-78. [CrossRef]

16. Garcia-Ispierto I, López-Gatius F. Effects of different five-day progesterone-based fixed-time AI protocols on follicular/luteal dynamics and fertility in dairy cows. $J$ Reprod Dev 2014; 60: 426-432. [Medline] [CrossRef]

17. López-Gatius F, Garcia-Ispierto I, Serrano-Pérez B, Hunter RHF. The presence of two ovulatory follicles at timed artificial insemination influences the ovulatory response to GnRH in high-producing dairy cows. Theriogenology 2018; 120: 91-97. [Medline] [CrossRef]

18. López-Gatius F. Is fertility declining in dairy cattle? A retrospective study in northeastern Spain. Theriogenology 2003; 60: 89-99. [Medline] [CrossRef]

19. García-Ispierto I, López-Gatius F, Bech-Sabat G, Santolaria P, Yániz JL, Nogareda C, De Rensis F, López-Béjar M. Climate factors affecting conception rate of high producing dairy cows in northeastern Spain. Theriogenology 2007; 67: 1379-1385. [Medline] [CrossRef]

20. López-Gatius F, Hunter R. Clinical relevance of pre-ovulatory follicular temperature in heat-stressed lactating dairy cows. Reprod Domest Anim 2017; 52: 366-370. [Medline] [CrossRef]

21. De Rensis F, Garcìa-Ispierto I, López-Gatius F. Seasonal heat stress: Clinical implications and hormone treatments for the fertility of dairy cows. Theriogenology 2015; 84 659-666. [Medline] [CrossRef] 